\title{
The influence of water price and the number of residents on the economic efficiency of water recovery from grey water
}

\author{
Maciej Dobrzański \\ maciej.dobrzanski@p.lodz.pl | (0) http://orcid.org/0000-0002-7112-0857 \\ Institute of Environmental Engineering and Building Installations, \\ Lodz University of Technology
}

Scientific Editor: Marek Piekarczyk, Cracow University of Technology Technical Editor: Aleksandra Urzędowska, Cracow University of Technology Press Language Editor: Tim Churcher, Big Picture Typesetting: Małgorzata Murat-Drożyńska, Cracow University of Technology Press

Received: May 27, 2020

Accepted: January 28, 2021

\begin{abstract}
Copyright: @ 2021 Dobrzański. This is an open access article distributed under the terms of the Creative Commons Attribution License, which permits unrestricted use, distribution, and reproduction in any medium, provided the original author and source are credited.
\end{abstract}

Data Availability Statement: All relevant data are within the paper and its Supporting Information files.

Competing interests: The authors have declared that no competing interests exist.

Citation: Dobrzański, M. (2021). The influence of water price and the number of residents on the economic efficiency of water recovery from grey water. Technical Transactions: e2021001. https://doi. org/10.37705/TechTrans/e2021001

\begin{abstract}
This article presents the results of an analysis of the economic viability of using an installation for the treatment of grey water. Economic indicators in the form of simple payback time (SPBT) and net present value (NPV) were used in the analysis. The use of a dual water supply system should theoretically enable the reduction of the costs of both water supply and sewage disposal, ensuring investment profitability. The article presents the impact of the number of residents as well as the impact of water and sewage on the profitability of using example water-recovery systems. It was found that both factors have a huge impact on the result of the economic analysis. For a small number of residents and at a low price of water supply and sewage disposal, it is not profitable to invest in a water-recovery system. This is due to the high price of purification devices.
\end{abstract}

Keywords: grey water, water price, economic analysis, water recovery, water supply, simple payback time, number of users 


\section{Introduction}

In urban areas, the most feasible method of reducing water consumption is the option of reusing grey water for toilet flushing, which can reduce individual in-house net water demand by 20-60 L/d per capita (Ghisi and Oliveira, 2007; Willis et al., 2011). If this practice becomes widespread, a reduction of up to 10-25\% of the urban water demand can be achieved (Fliedler and Hadari, 2006). Saving drinking water through the recovery of grey water will become commonplace only if this solution starts to generate economic profit (Mourad et al., 2011). The profitability of investing in water recovery is influenced by the type of building and its intended use, but the most influential factors are the number of inhabitantsand the price of water supply and sewage disposal. Most frequently, it is multi-family buildings, boarding houses, motels and hotels that are analysed because they are characterised by a large number of residents and the advantage of grey water over black water. Sgroi et al. (2018) discussed different political, social, economic, technological, and environmental factors that should be considered for a water reuse implementation, stating that the economic perspective is the greatest obstacle to the actual development of grey-water reuse (Sgroi et al., 2018). An example of this is the research carried out by Ghisi and Ferreira (2007) in three multi-family buildings in which water was recovered from grey water and/or rainwater. For two buildings, the highest profitability was found for the recovery of only grey water, obtaining a payback time in the range of 2-5 years. March et al. (2004) analysed the water-recovery system only from grey water in a hotel. It was found that the dual system was profitable, but the calculated payback time was up to 14 years. This was due to the short period of use of the facility over the course of a year. Zadeh S. et al. (2013) obtained a positive result in the economic efficiency analysis of a similar system in the case of a multi-family building (432 people), and negative result for an office building with almost twice as many users. The effect was the fact that, he volume of water recovered in the office building was too small in relation to the volume of water used to flush the toilets. Juan et al. (2016) proposed individual water recovery from grey water for apartments in a multifamily building in Taiwan. It was stated that this solution would be profitable after a period of twenty years of operation, only if the price for the water supply significantly increased by $500 \%$. This proves that the price of water supply is of great importance when analysing the economic efficiency of water recovery from grey water.

This article considers the question of at which number of users would a greywater-recovery system be economically viable in Poland. An analysis was also made at different prices for water supply and sewage disposal in the scope applicable in major Polish cities.

\section{Research methodology}

\subsection{Subject of research}

An economic efficiency analysis was used to study the impact of the number of people using the grey water-recovery system on the profitability of its use. The number of users in the range from two to fifty-five people was considered. The maximum number of users results from the limited flow efficiency of the adopted water-recovery system, which is described in the next paragraph. A constant level of water consumption of $120 \mathrm{dm}^{3} / \mathrm{d}$ per person was assumed, independent of the number of residents (Schuetze et al., 2013). The volume of water that could be replaced with water recovered from grey water was estimated to be $30 \%$ of the total water consumption. This is the average value of the percentage share of water used for flushing the toilet bowl according to many sources of literature (Memon et al., 2005; Yerri et al., 2019; Zadeh et al., 2013). 
In addition, it was assumed that sewage outflows from washbasins, washing machines and showers would fully cover the demand for recovered water. The grey-water-treatment system "GWTS" by Aqua2use (www.aqua2use.com) was used to calculate the costs associated with the treatment of grey water. This system is sold in three varieties GWTS 500, GWTS 1000 and GWTS 2000, differing with regard to the maximum flow capacity and price, which were $\$ 8,100$ (500 $\left.\mathrm{dm}^{3} / \mathrm{d}\right), \$ 9,900\left(1,000 \mathrm{dm}^{3} / \mathrm{d}\right)$ and $\$ 11,900\left(2,000 \mathrm{dm}^{3} / \mathrm{d}\right)$, respectively. Greywater-treatment technology is based on pre-filtration, biological purification and UV disinfection. A high degree of grey-water treatment should be applied because of the biological and chemical impurities that are present (Fliedler, 2014). The manufacturer ensures that the recovered water meets Australian standards for water intended for reuse in buildings. The operating costs of the system are primarily from electricity consumption at a level of around $2 \mathrm{kWh} / \mathrm{m}^{3}$ and the replacement of filters every six months at a price of $\$ 159$. In addition, it was assumed that a specialist would need to operate a system used for more than five people in order to replace filters and control the operation of the device. It was assumed that the location of the water-recovery system in the building was planned at the construction stage of the building.

\subsection{Economic analysis of the system}

As part of the economic efficiency analysis, gross profit was determined. This was estimated on the basis of the price and volume of tap water replaced by water recovered from grey water (1). The analysis assumed gross prices for water supply and wastewater disposal in most cities in Poland to be $8,10,12$, 14 and $16 \mathrm{PLN} / \mathrm{m}^{3}$. This article presents calculations in US dollars, assuming a dollar exchange rate of 3.80 . The price of water and sewage is $2.1 ; 2.6 ; 3.2 ; 3.7$ and $4.2 \$ / \mathrm{m}^{3}$, respectively, for the above prices in Polish cities.

Profit from recovered water was determined according to the formula:

$$
Z_{b r}=V_{s w} \cdot C_{w} \cdot T_{p}\left[\frac{\$}{\text { year }}\right]
$$

where: $V_{s w}$ - total volume of recovered water per day $\left[\mathrm{m}^{3} / \mathrm{d}\right] ; C_{w}-$ unit price for water supply and wastewater disposal $\left[\$ / \mathrm{m}^{3}\right] ; T_{p}$ - duration of system operation over the year [d] (assumed as 365 days).

Operating costs $K_{E}(2)$ were then calculated taking into account electricity consumption ( $0.14 \$ / \mathrm{kWh})$ in the form of a parameter $K_{E L}$ (3); filter changes twice per year $K_{w f}$ (\$159 per filter) (4); cost $K_{o b}$ of two service visits for a system supporting more than five people ( $\$ 105$ for visit). All operating cost was determined according to formula (2):

$$
\begin{gathered}
K_{E}=K_{E L}+K_{W F}+K_{o b}\left[\frac{\$}{\text { year }}\right] \\
K_{p}=V_{s w} \cdot P_{P} \cdot C_{e l} \cdot T_{p}\left[\frac{\$}{\text { year }}\right] \\
K_{w f}=n_{w f} \cdot C_{w f}\left[\frac{\$}{\text { year }}\right] \\
K_{o b}=n_{o b} \cdot C_{o b}\left[\frac{\$}{\text { year }}\right]
\end{gathered}
$$


where: $K_{E L}$ - total electricity cost [\$/year]; $K_{W F}$ - total cost of replacing filter cartridges [\$/year]; $K_{o b}$ - total system maintenance cost [\$/year]; $P_{p}$ - electrical energy usage $\left[\mathrm{kWh} / \mathrm{m}^{3}\right] ; C_{e l}$ - average price of electricity $[\$ / \mathrm{kWh}] ; n_{w f}$ - frequency of filter cartridge replacement per year [n/year]; $C_{w f}$ - unit price of the filter cartridge [\$]; $n_{o b}$ - system maintenance frequency [1/years]; $C_{o b}$ - the unit price of the service $[\$]$.

Simple payback time (SPBT) was then calculated taking into account operating costs (2). SPBT is a basic indicator of the economic profitability of investments in the recovery of grey water. It is assumed that a value below 15 years gives grounds to consider the investment to be profitable. Simple payback time was determined according to formula (6):

$$
\mathrm{SPBT}=\frac{K_{S}}{Z_{b r}-K_{E}}=\frac{K_{S}}{Z_{n t}}[\text { years }] \text {, for } Z_{n t}>0
$$

where: $K_{S}$ - system cost [\$]; $K_{E}$ - operating costs [\$/year]; $Z_{b r}$ - gross profit [\$/ year]; $Z_{n t}$ - net profit [ $\$ /$ year].

It should be noted that equation (6) is formulated in this study based on the literature (Juan et al., 2016). Based on the same data, the NPV (net present value) investment profitability ratio was determined (Pastusiak, 2010; Zadeh et al., 2012). The NPV indicates the difference between the discounted cost of using a water-recovery system for the assumed lifetime with the discount rate and the total cost of the system (equation 7).

$$
\mathrm{NPV}=\sum_{t=1}^{n} \frac{Z_{n t}}{(1+r / 100)^{t}}-K_{S}
$$

where: $r$ - discount rate [\%] (assumed to be 4\%); $t$ - assumed lifetime of the system [years] (assumed to be 15 years).

A negative NPV value indicates the economic unprofitability of the investment. When the NPV is zero, the analysed project is very susceptible to external factors, and the investor takes a high risk while implementing the investment.

\section{Results and discussion}

Taking into account the technical capabilities of the water-recovery system and the average water consumption, the relationship between the number of users and the system required for that number was estimated (Fig. 1). Assumptions regarding water consumption show that the volume of recovered water linearly changes relative to the number of users as a function of $V_{s w}=0.036 \cdot L_{o s}$ ( $L_{o s}$ - number of users). On this basis, it was determined that the GWTS 500, 1000 and 2000 systems adopted for analysis could support a maximum of 13, 27 and 55 residents, respectively. Therefore, we can assume it could be used in single-family buildings, small multi-family buildings or in small and mediumsized guesthouses and hotels.

Determining the volume of recovered water allowed the calculation of gross profit $Z_{b r}$. The net profit $Z_{n t}$ (Fig. 2) was then calculated taking into account the assumed operating costs. Net profit represents how much money we save every day thanks to the water-recovery system. Very often this indicator is used in marketing because it gives a distorted impression about the benefits of buying a water-recovery product.

Figure 2 shows that the value of net profit depends to a large extent on the number of people using the grey-water-recovery system but also on water and wastewater prices. The higher price significantly increases the profit from the grey-water-treatment system for the same number of users. In the case of buildings of up to five residents in which service costs were not included, net profit regardless of the water price variant takes negative values. This means 
Fig. 1. Change in the volume of water recovered in relation to the number of GWTS users (own studies)
Fig. 2. Relationship of net profit value to the number of GWTS users at different prices for water supply and sewage disposal (own studies)
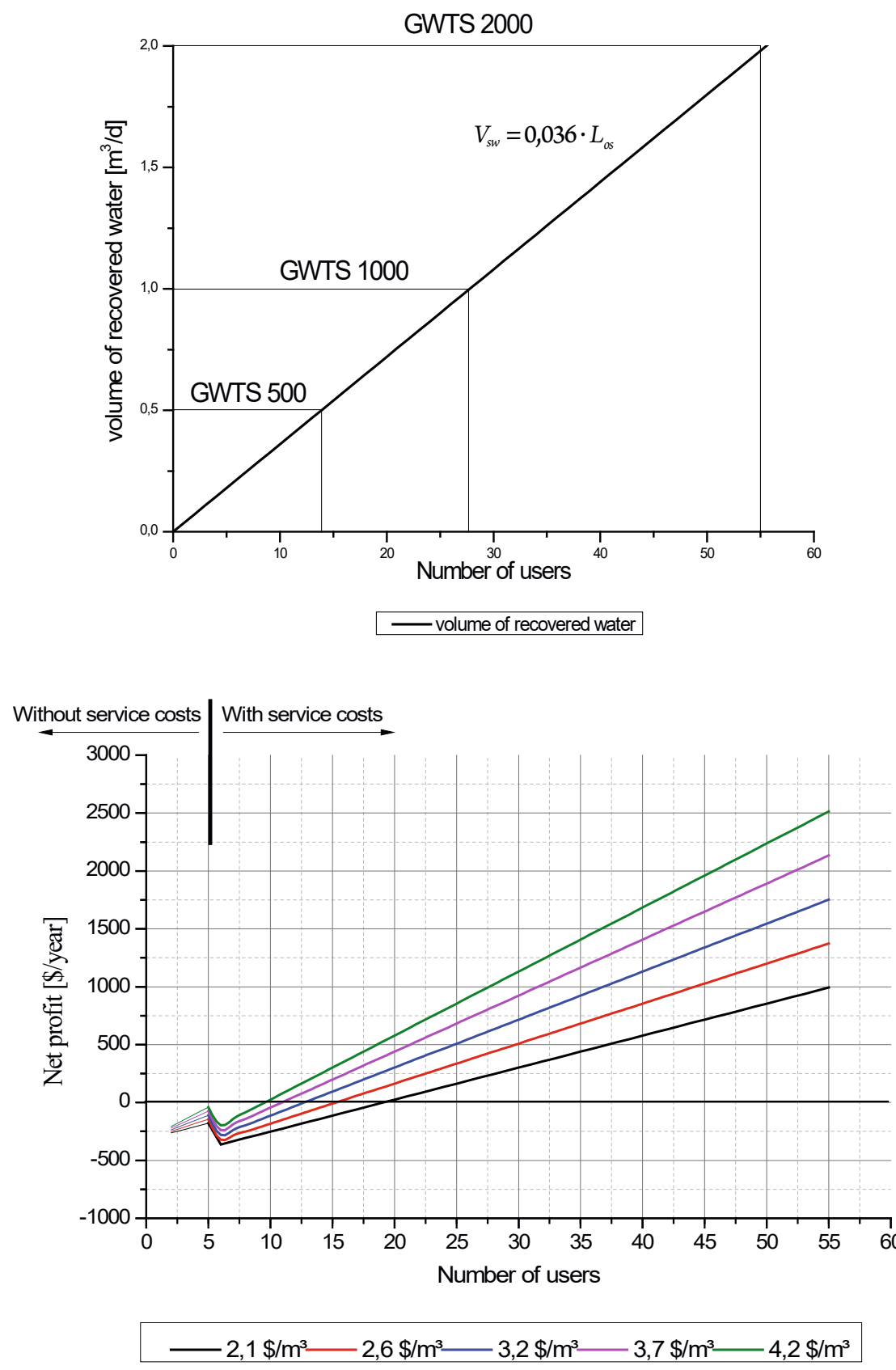

that using a water-recovery system is not economically viable. In the second variant with service costs (more than five users), the required number of people for a positive net profit decreases as the water and wastewater prices increase. At a price of $2.1 \$ / \mathrm{m}^{3}$ the minimum number of users is nineteen people, at 3.7 $\$ / \mathrm{m}^{3}$ it is thirteen people, and at $4.2 \$ / \mathrm{m}^{3}$ is only ten users. However, a positive net profit does not mean that an investment in a grey-water-reuse system will bring economic benefits. Its value must be high enough to recompense the investment costs incurred, i.e. primarily the cost of purchasing a grey-watertreatment device. This is represented by the SPBT indicator, the value of which indicates after what time the investment will start to bring real financial benefits. The calculated simple payback time is shown in Fig. 3. It excluded negative values of SPBT which were obtained for negative net profit and SPBT values for durations longer than 50 years.

As mentioned, when discussing the SPBT indicator, only results below fifteen years should be taken into account in analyses. Such a result is obtained for 


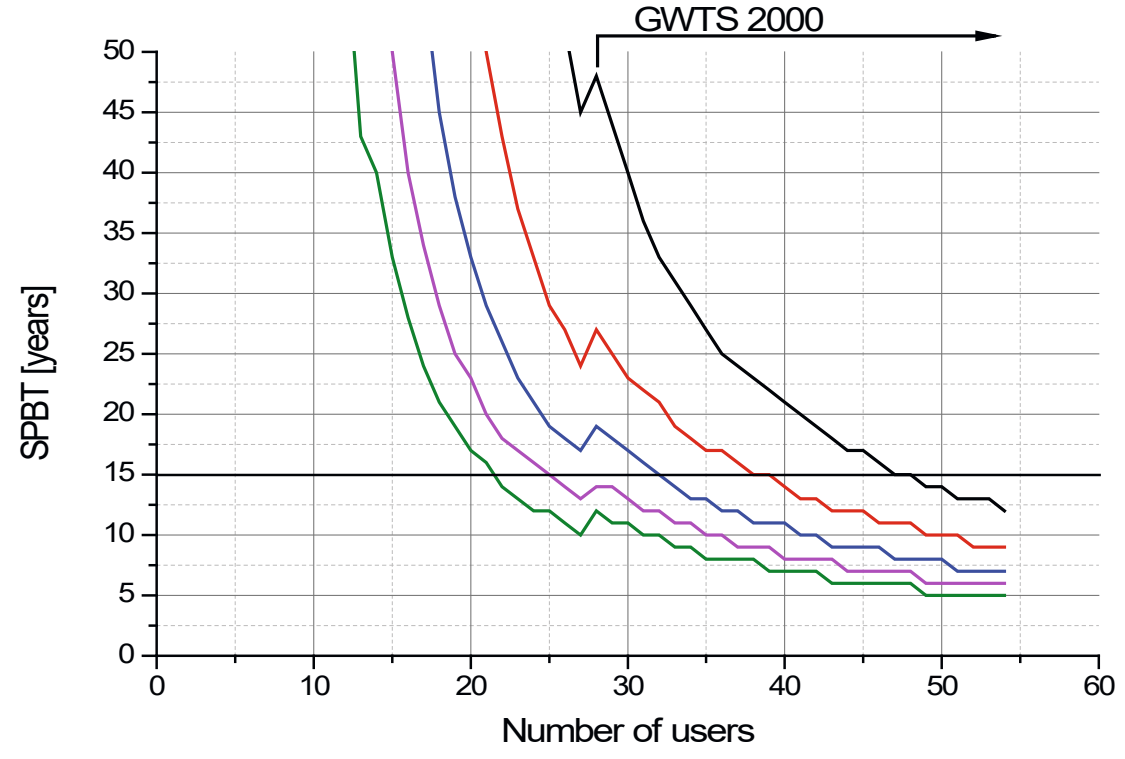

$-2,1 \$ / \mathrm{m}^{3}-2,6 \$ / \mathrm{m}^{3}-3,2 \$ / \mathrm{m}^{3}-3,7 \$ / \mathrm{m}^{3}-4,2 \$ / \mathrm{m}^{3}$

a price of $2.1 \$ / \mathrm{m}^{3}$ for buildings with over forty-eight residents, while at a price of $4.2 \$ / \mathrm{m}^{3}$, this number is half the size. The number of users required in this case is only twenty-one people. The results of the economic analysis are better for more people using the water-recycling system. Based on the SPBT value, it can be concluded that the best locations for using water recovery from grey water are towns in Poland with a water and wastewater price equal to or higher than $2.6 \$ / \mathrm{m}^{3}$. It then becomes profitable to invest in a water-recovery system for hotel facilities, boarding houses, motels and multi-family buildings. Figure 3 shows that buildings with less than ten residents receive a negative economic rating because the SPBT value is negative or higher than fifty years. The reason for this is the high cost of purchasing a grey-water-treatment device and high operating costs combined with a low price for water supply and sewage disposal.

In economics, and especially in the economic analysis of projects, the NPV investment profitability index is used much more frequently. Based on the NPV

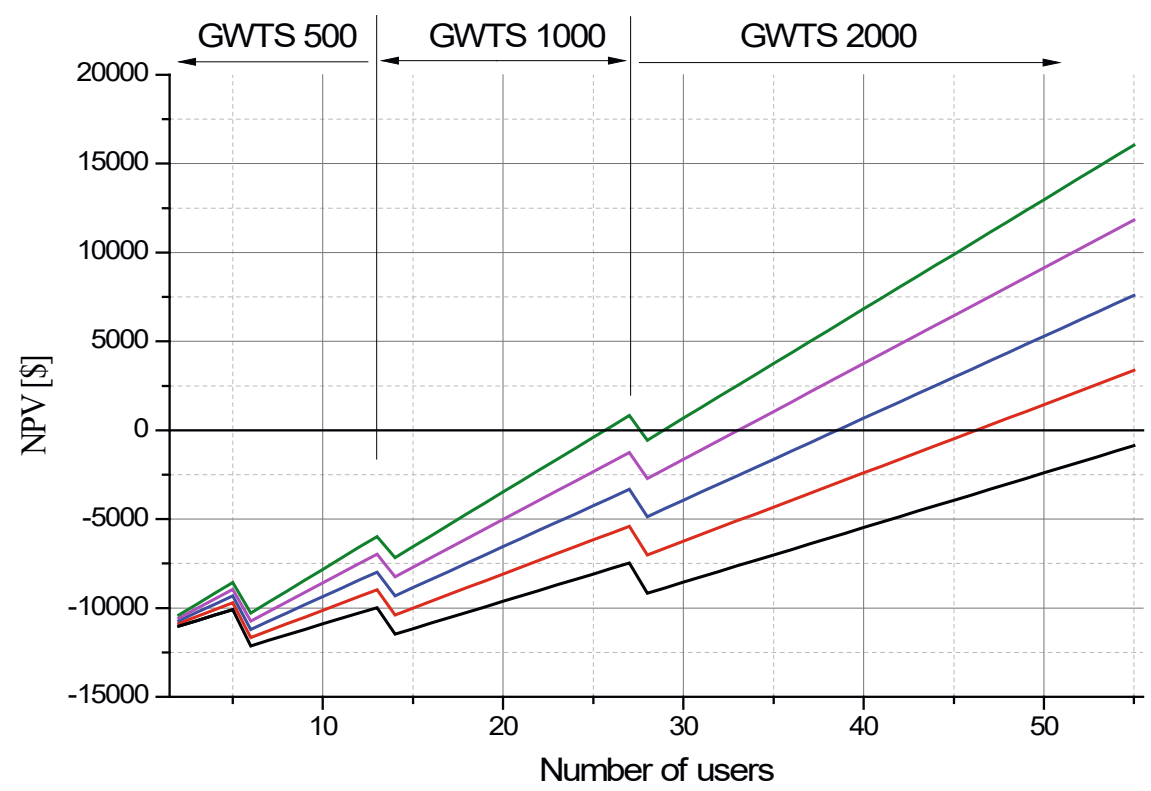

$-2,1 \$ / \mathrm{m}^{3}-2,6 \$ / \mathrm{m}^{3}-3,2 \$ / \mathrm{m}^{3}-3,7 \$ / \mathrm{m}^{3}-4,2 \$ / \mathrm{m}^{3}$
Fig. 3. SPBT value dependence on the number of GWTS users at different prices for water supply and sewage disposal (own studies)
Fig. 4. NPV value dependence on the number of GWTS users at different prices for water supply and sewage disposal (own studies) 
index, a much more accurate analysis can be performed. NPV takes into account changes in the purchase price (inflation) by presenting the total amount of return on investment over a given period. The calculated NPV is shown in Fig. 4. An abrupt change can be seen (at 5-6; 13-14 and 27-28 system users) in Figs. 3-6 because the cost of the system for more people increases and the cost of operating the system increases.

Based on Fig. 4, we can draw the following conclusions. At the $2.1 \$ / \mathrm{m}^{3}$ price variant, the water-recovery system, regardless of the number of users, is economically inefficient because NPV is negative, although earlier SPBT calculations may have suggested otherwise. Regardless of the price, investment in water recovery for facilities below twenty-five residents will only bring financial losses. Jodłowski and Dobrzański (2016) came to similar conclusions, analysing the water-recovery system they created themselves in a single-family building (Jodtowski, Dobrzański, 2016). The cost of their system was much lower than the Aqua2Use device investigated in this article. Additionally, Jabornig (2014), based on the economic analysis of various currently available technological solutions for the treatment of grey wastewater, came to the conclusion that their use in single-family houses is not justified.

The best NPV results were recorded for the prices of 3.2, 3.7 and $4.2 \$ / \mathrm{m}^{3}$, which is consistent with the conclusions drawn on the basis of a simple payback time. Assuming an installation of a system in a facility for around forty residents, for example in Tarnowskie Gory (current price of "water and wastewater" approx. $4.2 \$ / \mathrm{m}^{3}$ ), after fifteen years of operation of a grey-water-recovery system, we would obtain a total return on investment and a saving of around $\$ 15,000$.

There are cities in Poland where the price of water and sewage is definitely higher than the discussed price range. An example would be the town of Szklarska Poreba, where the price of water supply and wastewater disposal without municipal subsidies is $7 \$ / \mathrm{m}^{3}$. Only by municipal subsidies is the price maintained at 3.6 $\$ / \mathrm{m}^{3}$. Such a situation has a very negative impact on people's awareness of and willingness to invest in water recovery.

As can be seen in Fig. 5, the largest changes are observed for a small number of users. For example, the value of SPBT value of twenty-four years for twenty inhabitants decreases threefold to only eight years old. This means a much faster refund of costs incurred for the purchase of a water-recovery system. The assumed maximum payback time of fifteen years is already obtained with twelve residents. Based on Fig. 6, which presents a thorough economic analysis, it can be concluded that we should invest in a system of water recovery from

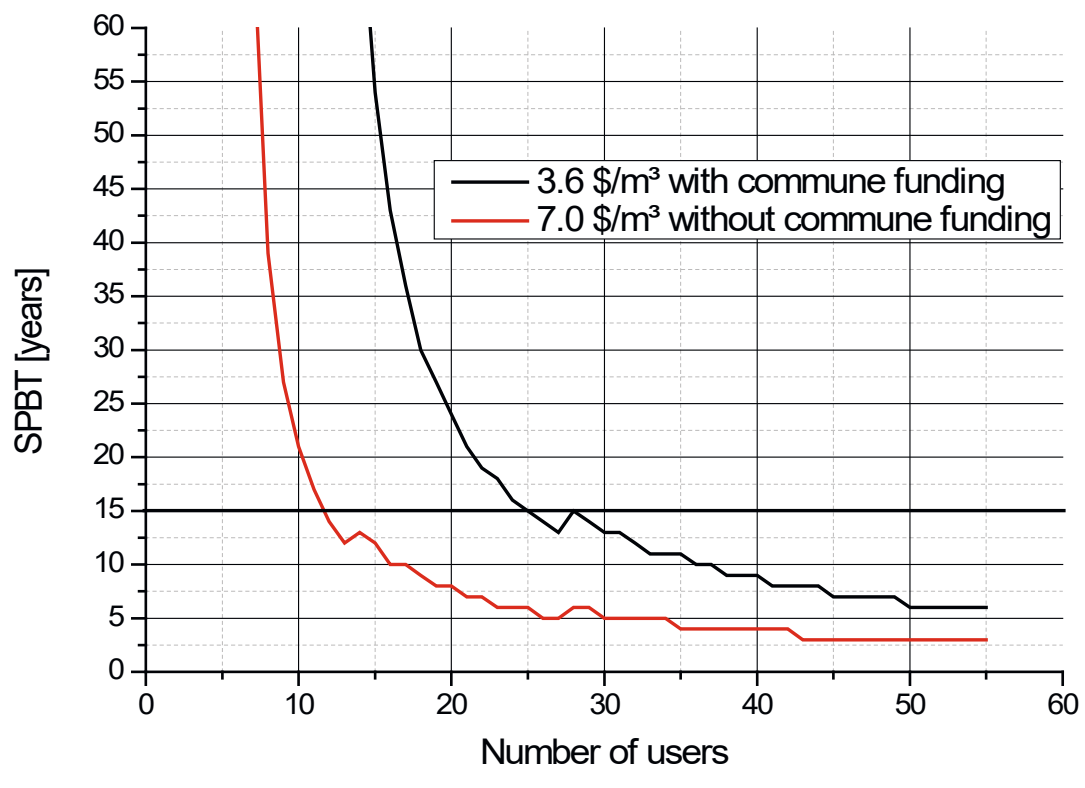




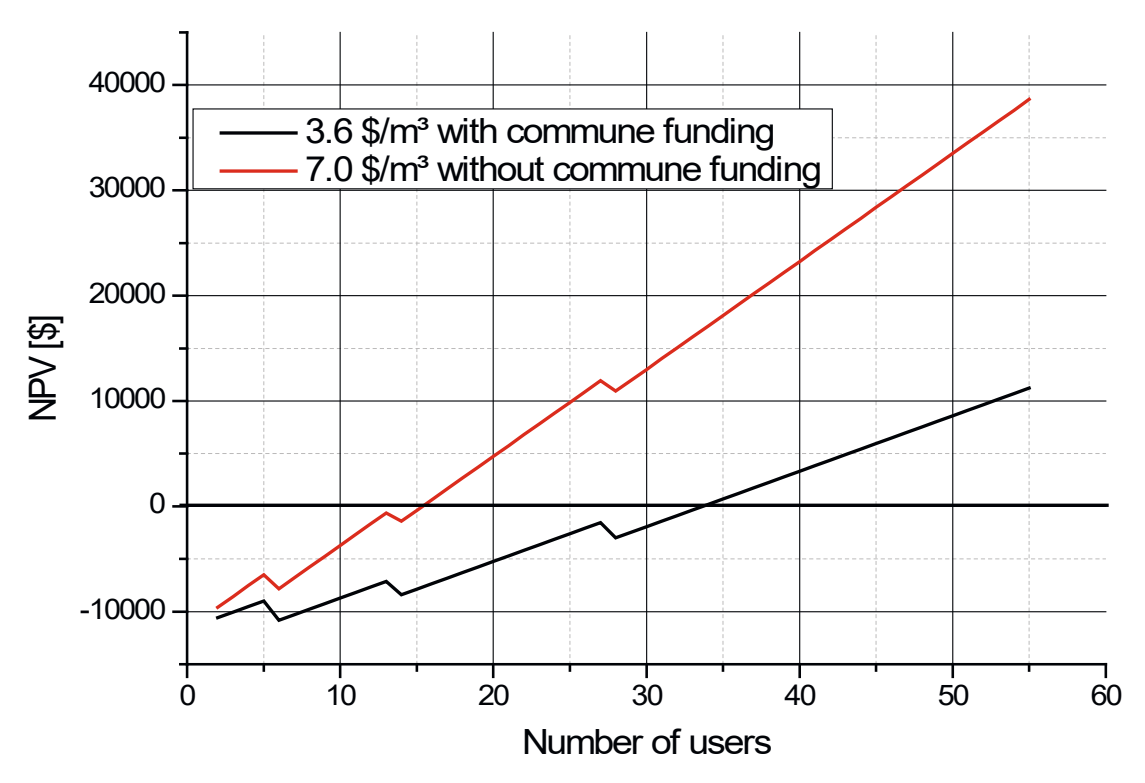

grey water in buildings with over sixteen people. Used as an example, Szklarska Poreba as a tourist destination, with a large number of guesthouses and hotels, is an ideal place for the use of water recycling.

\section{Conclusions}

In conclusion, we can say the price of water supply and sewage disposal has a greater impact on the results of the economic efficiency analysis than the number of users. This can be explained by a significantly increasing gradient of changes in NPV relative to the price of water, as in Fig. 4. In addition, it should be emphasised that the largest proportion of the costs concerning water and sewage is the price of sewage disposal. Thus, by utilising wastewater recycling, we can reduce the load on the sewage network and our own costs. The second proof of this is the existence of subsidies for high water prices, for example, in Szklarska Poreba. This disrupts the possibilities and benefits of using water recovery.

The second conclusion from the article is that the installation of grey-watertreatment systems in single-family buildings is economically unjustified because the purchase price of the system is too high in relation to the low price for water and wastewater. In economic terms, water-recovery systems should be used in facilities above $25,32,37$ or 45 residents, which correspond to prices of 4.2 , 3.7, 3.2 of $2.6 \$ / \mathrm{m}^{3}$, respectively, for water supply and wastewater disposal.
Fig. 6. NPV value dependence on the number of GWTS users in Szklarska Poreba city (own studies) 


\section{References}

Fliedler, E. (2004). Quality of individual domestic greywater streams and its implication for on-site treatment and reuse possibilities. Environ. Technol., 25(9), 997-1008. doi: 10.1080/09593330.2004.9619393

Fliedler, E., Hadari M. (2006). Economic feasibility of on-site greywater reuse in multi-storey builidings. Faculty of Civil and Environmental Engineering. Israel. 221-234. doi:10.1016/j.desal.2005.10.007

Ghisi, E., Ferreira, F.D. (2007). Potential for potable water savings by using rainwater and greywater in a multi-storey residential building in southern Brazil. Building and Environment, 42, 2512-2522. http://dx.doi. org/10.1016/j.buildenv.2006.07.019

Ghisi, E., Oliveira, S.M. (2007). Potential for potable water savings by combining the use of rainwater and greywater in houses in southern Brazil. Building and Environment, 42, 1731-1742. doi:10.1016/j.buildenv.2006.02.001

Jabornig, S. (2014). Overview and feasibility of advanced grey water treatment systems for single households. Urban Water, 11(5), 361-369. https://doi.org /10.1080/1573062X.2013.783086

Jodłowski, A., Dobrzański, M. (2016). Analiza ekonomiczna możliwości stosowania instalacji odzysku wody z szarych ścieków w gospodarstwach domowych i w hotelach. Instal, 3(371), 48-51.

Juan, Y-K., Chen, Y., Lin, J-M. (2016). Greywater reuse system design and economic analysis for residential buildings in Taiwan. Water, 8, 546. https:// doi.org/10.3390/w8110546

March, J.G., Gual, M., Orozco, F., (2004). Experiences on greywater re-use for toilet flushing in a hotel (Mallorca Island, Spain). Desalination, 164, 241247. https://doi.org/10.1016/S0011-9164(04)00192-4

Memon, F.A., Butler, D., Han, W., Liu, S., Makropoulos, C., Avery, L. M., Pidou, M. (2005). Economic assessment tool for greywater recycling systems. Engineering Sustainability, I58 Issue ES3, 155-161. https://doi. org/10.1680/ensu.2005.158.3.155

Mourad, K.A., Berndtsson, J.C., Berndtsson, R. (2011). Potential fresh water saving using greywater in toilet flushing in Syria. Journal of Environmental Management.,92,2447-2453.https://doi.org/10.1016/j.jenvman.2011.05.004

Pastusiak, R. 2010. Ocena efektywności inwestycji. Warszawa: CeDeWu.

Schuetze, T., Santiago-Fandiño V. (2013). Quantitative Assessment of Water Use Efficiency in Urban and Domestic Buildings. Water, 5, 1172-1193. https:// doi.org/10.3390/w5031172

Sgroi, M., Vagliasindi, F., Roccaro, P. (2018). Feasibility, sustainability and circular economy concepts in water reuse. Current Opinion in Environmental Science \& Health, vol. 2, 20-25. doi: 10.1016/j.coesh.2018.01.004

The Greywater Treatment System (2018). Retrieved from: www.aqua2use.com (access: 07/06/2018).

Willis, R., Stewart, R.A., Giurco, D.P., Talebpour, M.R., Mousavinejad, A. (2011). End use water consumption in households: impact of socio-demographic factors and efficient devices. Journal of Cleaner Production, 1-9. https:// doi.org/10.1016/j.jclepro.2011.08.006

Yerri, S., Piratla, K. (2019). Decentralized water reuse planning: evaluation of life cycle costs and benefits. Resour. Conserv. Recycl., 141, 339-346. https:// doi.org/10.1016/j.resconrec.2018.05.016

Zadeh, S., Hunt, D., Lombardi, R., Rogers, Ch. (2013). Shared urban greywater recycling systems: water resource savings and economic investment. Sustainability, 5, 2887-2912. https://doi.org/10.3390/su5072887

Zadeh, S., Lombardi, R., Hunt, D., Rogers, Ch. (2012). Greywater Recycling Systems in Urban Mixed-Use Regeneration Areas: Economic Analysis and Water Saving Potential. MDPI AG in the 2nd World Sustainability Forum session Sustainable Urban Development. 


\section{Wpływ ceny wody i liczby mieszkańców na efektywność ekonomiczną odzysku \\ wody z szarych ścieków}

\section{Streszczenie}

Wartykule przedstawionowynikiekonomicznejanalizyopłacalnościzastosowania instalacji do oczyszczania szarych ścieków. W analizie zastosowano wskaźniki ekonomiczne w postaci prostego czasu zwrotu (SPBT) i wartości bieżącej netto (NPV). Zastosowanie podwójnego systemu zaopatrzenia w wodę powinno teoretycznie pozwolić na obniżenie kosztów tego zaopatrzenia i odprowadzania ścieków, zapewniając opłacalność inwestycji. W artykule przedstawiono wpływ liczby mieszkańców, a także ceny wody i ścieków na opłacalność wykorzystania przykładowych systemów odzyskiwania wody. Stwierdzono, że oba czynniki mają ogromny wpływ na wynik analizy ekonomicznej. Dla niewielkiej liczby mieszkańców i przy niskiej cenie wody i ścieków nie opłaca się inwestować w system odzyskiwania wody. Wynika to z wysokiej ceny urządzeń do oczyszczania.

Stowa kluczowe: szare ścieki, cena wody, analiza ekonomiczna, odzysk wody, zaopatrzenie w wodę, prosty czas zwrotu, liczba mieszkańców 